CESIS Electronic Working Paper Series

Paper No. 385

Innovation and entrepreneurship in the global economy

\author{
Charlie Karlsson \\ Urban Gråsjö \\ Sofia Wixe
}

November, 2014 


\title{
Innovation and entrepreneurship in the global economy
}

\author{
Charlie Karlsson ${ }^{1}$, Urban Gråsjö ${ }^{2}$ \& Sofia Wixe ${ }^{3}$
}

\begin{abstract}
Much of the discussion about globalization has been held at a rather superficial macroeconomic level. Discussions about globalization dealing with the meso- and microeconomic level, i.e. the level of regions and companies, have been much less common. Many of the discussions of globalization at the meso- and micro-economic level have also been biased in the sense that they have only given a partial picture. One obvious example is that discussions of the role of innovation and entrepreneurship have tended to use a narrow definition of entrepreneurship equal to the start-up of new companies and as a result ignored the high degree of innovation and entrepreneurship within many incumbent companies. The purpose of this paper is to contribute to the meso- and micro-economic literature on innovation and entrepreneurship in the global economy.
\end{abstract}

Keywords: Globalization, innovation, entrepreneurship, urban regions

JEL codes: F6, O3, R1, L26

\footnotetext{
${ }^{1}$ Jönköping International Business School, Jönköping, Sweden, E-mail: charlie.karlsson@jibs.hj.se

${ }^{2}$ University West, Trollhättan, Sweden, E-mail: urban.grasjo@hv.se

${ }^{3}$ Jönköping International Business School, Jönköping, Sweden, E-mail:sofia.wixe@jibs.hj.se
} 


\section{Introduction}

We have in recent decades been able to witness a veritable revolution in the world economy, with dramatic changes in the competitiveness of nations, regions and companies. The most commonly used term to describe this revolution has been 'globalization', even if there in the literature exist no common definition of this term. Actually, all definitions of globalization are elusive and elicits criticism (Thurik, et al., 2013). Generally, the term is connected to the rapid increase of the free movement of goods, capital, people, ideas, information and knowledge around the globe. In fact, the shift of economic activities between regions in different national spheres ranks among the most vigorous changes shaping the economic landscape of today (Dreher, et al., 2013).

Much of the discussion about globalization has been held at a rather superficial macroeconomic level. Discussions about globalization dealing with the meso- and micro-economic level, i.e. the level of regions and companies, have been much less common. Many of the discussions of globalization at the meso- and micro-economic level have also been biased in the sense that they have only given a partial picture. One obvious example is that discussions of the role of innovation and entrepreneurship have tended to use a narrow definition of entrepreneurship equal to the start-up of new companies and as a result ignored the high degree of innovation and entrepreneurship within many incumbent companies. This is problematic since innovation and entrepreneurship generating new technologies, new products and new production processes are at the core of economic development and growth (Hall, 1999).

The purpose of this paper is to contribute to the meso- and micro-economic literature on innovation and entrepreneurship in the global economy.

\section{Globalization}

There is a tendency in the current literature to treat globalization as a new phenomenon that started to emerge in the postwar period. This can certainly be questioned (Kenwood \& Lougheed, 1999; Taylor, 2002; Karlsson, Johansson \& Stough, 2010) but is of lesser importance here since we focus on the current wave of globalization. Some authors claim that it was the break-down of the Soviet Union and the Warsaw Pact highlighted by the fall of the Berlin Wall possibly together with the changes in China towards more of a market economy that kicked-off the current wave of globalization (Thurow, 2002). However, these important historical events did not start the current wave of globalization but they gave substantially more energy by opening up "fertile land" for the globalization efforts.

The original motor behind the current wave of globalization was the drive among large manufacturing companies, who via foreign direct investments (FDIs) on top of their export efforts, wanted to get control over raw material sources as well as increase their sales. By production in other countries, it was possible to overcome tariffs and other trade impediments and at the same time adapt their goods to the customers' preferences and willingness to pay in these countries. These firms represents the managed economy, where economic performance is 
positively related to firm size, scale economies and routinized production and innovation (Thurik, et al., 2013).

In recent decades, this motor has been complemented by a second motor that we can term the 'entrepreneurship motor' representing the wave of new firm formation and new firm growth coming from new technological fields, such as microelectronics, software and bio-technology (cf. Koellinger \& Thurik, 2012). These firms represent the entrepreneurial economy, where economic performance is related to distributed innovation and the emergence and growth of entrepreneurial ventures (Audretsch \& Thurik, 2001). Entrepreneurship in the sense of new firm formation is of course critical, since it plays a fundamental role in fostering competition, inducing innovation and fostering the emergence of new industries (Dejardin, 2011). Over the years there are many processes that have contributed to stimulate globalization and to shift the comparative advantages for different types of economic activities between countries making it possible and even essential to locate many new capital investments, i.e. factories, plants and establishments, to low-cost locations outside the US and Western Europe (Audretsch, 2010). These processes (in no particular order) include:

- The reduction of tariffs and trade barriers, first via GATT and later via WTO.

- The creation and enlargement of the EU and the creation of NAFTA and other free trade blocks.

- The establishment of a global air travel network.

- The rapid expansion of the highway networks increasing the reliability of truck transports.

- The rapid growth of container transports.

- The deregulation of many markets and in particular the financial markets.

- The emergence of global financial markets with large and rapid flows of capital between different global financial centres.

- The establishment of global technological standards.

- The information and communications technology (ICT) revolution and the establishment of the Internet and a much more rapid diffusion of large volumes of standardized information (Castells, 1996).

- The emergence of a global just-in-time media coverage (Karlsson \& Picard, 2011).

- The emergence of a global knowledge economy ${ }^{4}$ via

○ rapidly increasing investments in knowledge production, i.e., in particular $\mathrm{R} \& \mathrm{D}$, with important breakthroughs in many research fields, not least related to microelectronics, and

○ rapidly increasing investments in higher education in an increasing number of countries.

- Substantial increases in international migration, in particular, among highly educated groups of people.

- Increasing real incomes resulting in a larger demand for diversity in consumption.

\footnotetext{
${ }^{4}$ Also known as a 'knowledge society', a ‘learning economy', an 'innovation economy', an 'innovative economy', an 'e-economy', a 'creative economy' and a 'new economy', cf. Dubina, et al., 2011.
} 
- An increasing number of people in the world has come out of poverty.

- The introduction of new computerized design and production methods, which increased the flexibility in production and allowed for more or less instant shifts between models produced to meet the rapidly shifting demands among customers with a taste for diversity.

- New methods to organize production with more flat organizations using ICT solutions and with increased used of external suppliers via out-sourcing and offshoring to gain lower costs by taking advantage of internal scale economies among suppliers.

- A rapid increase of intra-industry trade to take advantage of internal economies of scale in production.

- A rapid increase in the number of multinational firms (MNFs) and in the number of MNF affiliates.

The above list clearly illustrates that the current wave of globalization has been intimately connected with an overwhelming number of product, process, input, market, and organizational innovations clearly illustrating that this wave of globalization also has been a period of exceptional entrepreneurship both among large multinational firms and among independent entrepreneurs. However, creativity, innovation and entrepreneurship have not been present everywhere. On the contrary, they have been strongly concentrated to a limited number of large urban regions in the richer countries in the world (Montgomery, 2008; Florida, 2009), even if of course, creativity, innovation and entrepreneurship can and do occur in non-urban economic milieus (Shearmur, 2012).

\section{Innovation, entrepreneurship and large urban regions}

Despite all the claims about "the death of distance" or "the world is flat", it becomes more and more obvious that location matters for creativity, innovation and entrepreneurship, and, in particular, a location in large urban regions. Why is this the case? What is it that large urban regions offer that are so critical for creative, innovative and entrepreneurial activities? One factor is that they contain concentrations of organizations, such as research universities and R\&D labs, that are direct or indirect generators of innovations and entrepreneurship (Acs, 2002). Another factor is that creative, innovative and entrepreneurial people are attracted to large diversified cities (Florida, 2002; Landry, 2008) and that companies that locate in such regions tend to be more innovative and entrepreneurial, either through learning or through sorting, i.e. companies draw upon, or adapt to their regional environment (Doloreux, 2005).

Even if it is widely accepted that the internal capacities and activities in companies are critical for their innovative and entrepreneurial capacity (Lichtenhaler \& Lichtenhaler, 2009), it is also widely recognized that a primary factor affecting a company's innovative and entrepreneurial capacity is its openness to external sources of information, knowledge and collaboration. Large urban regions are information-, knowledge- and contact-rich economic milieus both in intra- and inter-regional terms, since they are not only built up by innumerable interconnected networks but also by nodes connected to other large urban regions in a space of information and knowledge flows (Castells, 1996). Hence, it is optimal for innovative and 
entrepreneurial companies to locate in such regions to maximise their chances of obtaining appropriate information and knowledge, of identifying opportunities, and of finding appropriate suppliers, labour, collaborators and clients (Sedgley \& Elmslie, 2011). These regions also offer the best conditions for potential entrepreneurs to actually become entrepreneurs.

It costs more for a company to be located in a large urban region and it is only those companies whose innovation capability requires intense and frequent interactions with other economic agents, who will pay the extra costs for such a location (McCann, 2007). These companies are usually dealing with the most knowledge-dependent and uncertain innovations and are dependent on trial and error and close cooperation with customers and/or suppliers (cf., Duranton \& Puga, 2001). These general conclusions do not preclude that in some industries companies may avoid industry clusters in cases where the risk for regional spillovers of critical knowledge to competitors is very high (Suarez-Villa \& Walrod, 1997). However, innovations developed outside the large urban regions normally only reach their full commercial potential if they are introduced, further developed and marketed in a large urban region. All together this points in the direction that large urban regions are the loci of innovation and entrepreneurship because the economic agents with the social and market power to promote them tend to reside and have their activities there (Yeung, 2005).

The critical role of large urban regions depend upon that companies and entrepreneurs innovate in an open fashion, i.e. they rely on face-to-face interaction with other economic agents, which is greatly facilitated by the economic milieu offered by large urban regions due to their higher physical proximity (Storper \& Venables, 2004). The much richer options for face-to-face interaction in these areas are important not only because the transfer of complex, uncertain and partly tacit knowledge often needs repeated face-to-face interactions but that such options open up more chances for unscheduled or serendipitous encounters, which are the encounters that are most likely to result in the juxtaposition of different types of information and knowledge, which through creative processes might lead to innovations and new entrepreneurial actions (Godoe, 2012). Boschma (2005) remarks that there exist several more proximities that are important for creativity, innovation and entrepreneurship. They include social proximity (e.g., friendship ties), organizational proximity (e.g., working for the same company or company group), cognitive proximity (e.g., having the same knowledge base), and 'institutional' proximity (e.g., working under similar formal and informal institutions). One might very well also add occupational proximity, i.e., having the same type of occupation and supplier-customer proximity in terms of types and frequency of deliveries. However, Boschma misses that the strength of all these different proximities is a function of the geographical proximity.

Thus, large urban regions are conducive to creative, innovative and entrepreneurial processes and this claim is supported by a variety of different types of empirical evidences. They generate more patents per capita than smaller regions (Bettancourt, et al., 2007), are the locations where world-first new products and radical innovations are introduced (Audretsch \& Feldman, 1996), and are the locations where new industries emerge (Duranton \& Puga, 2001). It is against this background obvious that large urban regions and creativity, innovation and 
entrepreneurship are intrinsically interlinked in numerous ways. Thus, large urban regions tend to evolve in a path-dependent fashion (Neffke, et al. 2011) based upon the internal and external information-, knowledge- and contact-links they offer. This implies that most of the innovations and the entrepreneurship that emerges in such regions are related to their historical industrial structure and knowledge supply.

There exists a long-standing controversy concerning what type of urban region that provide the most fertile ground for innovation and entrepreneurship (cf. Glaeser, et al., 1992). According to the so-called Marshall-Arrow-Romer (MAR) model, it is the concentration of a particular industry within a specific urban region that promotes intra-regional knowledge spillovers across economic agents that stimulates innovation and entrepreneurship in that region and within that particular industry. Research on cluster dynamics stress the importance of interactions between companies in the same industry for innovation (Wolfe, 2009). According to this perspective, companies in the same industry share similar infrastructure needs, labour forces, suppliers, and markets. It is assumed that such localization economies, combined with knowledge spillovers, provide the necessary pre-conditions for innovation and entrepreneurship.

Jacobs (1969) presented an alternative hypothesis saying that the general agglomeration of companies in urban regions fosters innovation and entrepreneurship due to the diversity, variety and complementarity of the knowledge sources located in the region (Desrochers, 2001). Here it is chance encounters and the combination of knowledge from unexpected sources that enhances innovation and entrepreneurship. However, it is not only the diversity of economic actors and the knowledge base, but, increasingly, the diversity of the ethnic, cultural and social fabric that is seen as a prerequisite for creativity, innovation and entrepreneurship (Niebuhr, 2009). Thus, it seems clear that whatever the ways in which entrepreneurs and companies draw upon their external economic and knowledge milieu to innovate and to be entrepreneurial, this milieu is richer, more knowledge-intensive, more diverse and more highly specialised in all dimensions in large urban regions than in smaller urban and non-urban regions (Glaeser, 2011). We must also remember that there probably exists optimal levels of diversity or heterogeneity (Fujita, 2009) and that over time heterogeneity might lead to homogeneity in the absence of stochastic processes stimulating heterogeneity.

Despite many empirical studies trying to solve this controversy, no definitive answer has yet been presented. Perhaps is it the case that other underlying factors determine, which type of knowledge spillovers are most important in different urban regions. Actually, it is rather unlikely that one single process should prevail (Iammarino, 2011). Depending upon differences in historical trajectories, existing industrial specializations and knowledge bases, external pressures and public policies, we can imagine that it is possible to identify a number of different typical development paths for urban regions.

Another and related controversy circles around the question whether it is weak or strong regional competition that is more conducive to innovation and entrepreneurship in an urban region. According to the MAR model weak regional competition is superior to strong regional 
competition since it enhances that ability of companies and entrepreneurs to appropriate the economic value of their innovative and entrepreneurial activities. Porter (1990), on the other hand, maintains that competition is more conducive to innovative and entrepreneurial activities.

One might claim that the above discussion suffers from a basic static bias. It tends to neglect that the life cycle stage within which an industry is operating contains answers to questions such as who are the innovators and the entrepreneurs, how much innovative and entrepreneurial activities are undertaken and where do the innovative and entrepreneurial activities take place (cf., Klepper, 1992). It also neglects that decisions on organizational factors within companies such as vertical integration and choices on innovation and location are strategic decisions and thus evolves as markets, technologies and politics change (Chandler, et al., 1999). Within such a context, the location of innovative and entrepreneurial activities is determined by the accessibility to the necessary market and input conditions including accessibility to the necessary knowledge inputs not least via intra- and interregional knowledge spillovers. The industry life cycle is often described as containing the following stages (Williamson, 1975):

- The first, early formative innovative and entrepreneurial stage involves that the supply of a new product is normally different producers offering different but varying and rather primitive designs produced using highly skilled workers and comparatively unspecialized machinery in one nursery city or a limited number of nursery cities (Duranton \& Puga, 2001) in one country and sold in small quantities to advanced and demanding customers mainly located in large urban regions in the home country. The business experience during this stage is characterized by a high degree of uncertainty and it is typical that many of the early entrepreneurs fail for various reasons.

- The second, intermediate development stage is characterized by the emergence of a dominant design, the use of more refined manufacturing techniques, a rapid increase in output from remaining companies as new applications are recognized and the unsatisfied demand increases, since the new product has proven its value for larger groups of customers. Uncertainties concerning products, production processes, markets and competitors are now reduced and to take advantage of existing internal economies of scale, companies now increasingly try to serve foreign markets by means of exports.

- The third, mature stage with fully standardized products and production processes is characterized by an advanced refinement of production, marketing and management techniques and increased focus on cost control while serving growing markets. Radical innovations are scarce and most innovations have the form of marginal improvements. New large scale integrated production facilities are now established in locations in the hinterland of large cities with a strong logistic position, in low cost locations in more peripheral locations in the own country (Rees, 1979), and close to the market in foreign countries by means of foreign direct investments (Vernon, 
1966). Various efforts are made to "bind" customers to their current supplier to fend off major competitors.

Due to the introduction of computerized flexible production systems, the rapid improvements of information and communication technologies, and the improvements in transport networks it is possible to identify also a fourth stage of knowledge-based fragmentation and differentiation. This stage opened up new options in market economies and increased the number of options open to companies.

It became possible not least for the large multinational companies to fragment the different production steps, locate them in the region in the world offering the best location conditions and still maintain control of their global production networks ${ }^{5}$ (Coe, et al., 2008) via network control (Warda, 2013). These companies could introduce new business models (Brynjolfsson \& Hitt, 2000), and scale down their large inflexible production facilities and in a systematic manner start to out-source and even off-shore production stages. Newly established companies could avoid investing in large-scale integrated production facilities and take advantage of out-sourcing and off-shoring from the very beginning. This out-sourcing and off-shoring manifested itself in the form of outward foreign direct investments from the developed countries (Friedman, 2005). By out-sourcing/off-shoring the production of parts and subsystems, companies can lower their costs, since they can take advantage of suppliers' location cost advantages and internal economies of scale - scale economies that they cannot achieve themselves with in-house production due to too small production series. However, out-sourcing/off-shoring is not limited to various types of inputs and services. Increasingly companies out-source $R \& D$ to take advantage of unique knowledge in specialized $R \& D$ companies and off-shore R\&D activities to those large urban regions where competitors have located their R\&D and/or where leading research universities do high-quality $R \& D$ of special interest to the company. This reorganization of large companies opened up opportunities for spin-offs and new roles for small entrepreneurial firms (Klepper \& Thompson, 2010).

Another major advantage for companies of the radical new way to organize and control production is that it is much easier to produce differentiated outputs to meet customers' demand for variety but also take advantage of the differences among customers in the capacity and willingness to pay for different product attributes. Customers' demand for variety also make it possible for new entrepreneurs to enter the market to serve distinct small groups of customers with specific product varieties.

If we summarize the above discussion we see that we can identify two main groups of actors in the market place behind the ongoing transformations. On the one hand, we have a large and increasing number of multinational firms that use all the options opened up by the current wave of globalization and by the many important technological changes that have taken place alongside. They have reorganized their production chains by means of out-sourcing and not least off-shoring of parts of their production to lower-cost locations, often in other countries, which generally have preserved the viability of many of these multinational firms (Audretsch

\footnotetext{
${ }^{5}$ Some authors use the parallel concepts 'global commodity chains' and 'global value chains' (Henderson, et al., 2002).
} 
\& Thurik, 1999). The result has often been a substantial downsizing in terms of total employment but a shift to a substantially higher share of highly skilled employees, resulting in a divergence of unemployment rates between high-skilled and low-skilled workers (Mankiew \& Swagel, 2006).

On the other hand, we have a myriad of entrepreneurs who have launched their new businesses and often failed but where a limited number has succeeded by often launching radical innovations that have created totally new industries and changed the way we organize production and do business including the out-sourcing and off-shoring of non-core business activities (EIM, 2009). This 'entrepreneurial revolution' has partly been stimulated by the corporate reorganization leading to new organizational structures in large as well as small and medium-sized firms and partly by a higher emphasis on knowledge as a production factor, and has opened up new opportunities for spin-offs and new roles for small and medium-sized firms (Klepper \& Thompson, 2010). However, higher real income levels have also opened up new entrepreneurial opportunities by leading to a more service-oriented economy (Bryson, et al., 1997), a differentiation in consumer demand (Piore \& Sabel, 1984), and a shift in occupational preferences (Uhlaner \& Thurik, 2007). To stay competitive in this 'new knowledge economy', small and medium sized firms have increased their spending on R\&D and thus increased their share of total private R\&D (Mowery, 2009).

An interesting thing with much of the recent globalization literature is that it mostly has concentrated on one of these processes and obviously has not understood that there has been two very strong parallel processes that in a couple of decades has transformed both the structure and the location of the private sector within as well as between countries. As globalization spreads, employment tend to stop increasing and often even to start decreasing in the large, incumbent mainly multinational firms, generating entrepreneurial opportunities for new firms and for existing small and medium-sized firms (Thurik, et al., 2013). It is often not noticed that some of todays' larger multinational companies were founded by entrepreneurs a decade or a few decades ago.

\section{Policy response to globalization}

Against the above background, which is the proper policy response to globalization and its very distinct effects? The public policy debate has more and more come to stress knowledge and ideas as the source of competitiveness and economic growth. This policy focus is supported in the economics literature, where knowledge and ideas have emerged as critical growth factors in the new endogenous growth theory (Lucas, 1988; Romer, 1990). The endogenous growth theory assumes that knowledge has the character of a public good and that an entire economy automatically benefits from its investments in $R \& D$ and education through spillovers. In particular, it is the possibility that more than one firm or economic agent can use a certain piece of knowledge that is particularly conducive to economic growth. Although there is, of course, a great deal of evidence that access to knowledge (R\&D stock and human capital) leads to economic growth, some countries seem to benefit more from investments in knowledge than others. 
National governments have also begun vigorous and targeted efforts to spur the start-up and growth of new firms, i.e., entrepreneurship policies (Karlsson \& Andersson, 2009). An important implication of the current wave of globalization is that focusing on entrepreneurship polices ignores the pervasiveness and the prevalence of the underlying forces. Promoting new firm formation and/or their post-entry performance is an all too narrow interpretation of the appropriate public policy response. Rather than to develop an entrepreneurship policy, the appropriate policy response is to develop policy for an economy where large multinational firms co-exists with vibrant entrepreneurial firms and where firms of different sizes increasingly co-operate via out-sourcing and off-shoring.

The impact of technological change and its many mediators on all types of firms is so complex and so pervasive that the policy implications are beyond creating an entrepreneurship policy to support other public policy avenues. Rather than a narrow focus on promoting new firm formation and/or growth of new firms, the appropriate policy response is to re-engineer the public policy response in a broad and pervasive sense and develop policies for a dynamic, self-renewing market economy with a sound mix of small and medium-sized firms as well as large multinational firms in which entrepreneurship plays a key role (Acs, 2006). This implies the formation of formal institutions that, for example, reduce the barriers and costs of entry and growth of firms, facilitate the sectoral and spatial mobility of resources, in particular labour and capital, stimulate investments in R\&D and education, and increase the openness of the national economy for international competition (cf., Kirchoff, 1994).

However, the increased sensitivity among companies for the location conditions offered in different regions has changed the public policy arena. The ability of national governments to control the behaviour of companies have been reduced not least due to the deregulation over broad sectors. International competition is becoming less of a competition between nations and increasingly a competition between regions, where the options for many regions due to lack of resources often are quite limited. Poor regions main competitive advantage is low costs given that they not dispose a rich source of unique raw materials. Large and rich urban regions on the other hand have many options to compete with superior material infrastructures, a good housing infrastructure rich with amenities, a well-educated labour force and high-quality universities. What limits the actions of large and rich urban regions are the lack of regional government and that the national government controls many critical areas such as transport infrastructure, higher education and public financing of R\&D. Anyhow, the large and rich urban regions will at large keep their position as hotspots for innovation and entrepreneurship for a substantial time.

\section{Concluding remarks}

The purpose of this paper was to contribute to the meso- and micro-economic literature on innovation and entrepreneurship in the global economy. For researchers the current wave of globalization offers innumerable interesting and important research questions. A few of these research questions was highlighted above. Much of the discussion about globalization has been held at a rather superficial macroeconomic level. Discussions about globalization dealing with the meso- and micro-economic level, i.e. the level of regions and companies, 
have been much less common. Many of the discussions of globalization at the meso- and micro-economic level have also been biased in the sense that they have only given a partial picture. One obvious example is that discussions of the role of innovation and entrepreneurship have tended to use a narrow definition of entrepreneurship equal to the start-up of new companies and as a result ignored the high degree of innovation and entrepreneurship within many incumbent companies.

\section{References}

Acs, Z.J. (2002), Innovation and the Growth of Cities, Edward Elgar, Cheltenham

Acs, Z.J. (2006), How Is Entrepreneurship Good for Economic Growth? Innovations, Technology, Governance, Globalization 1, 97-107

Acs, Z.J., et al. (2012), Growth and Entrepreneurship, Small Business Economics 39, 289-300

Audretsch, D.B. (2010), Globalization and the Emergence of the Entrepreneurial Society in Karlsson, C., B. Johansson \& R.R. Stough (Eds.), Entrepreneurship and Regional Development. Local Processes and Global Patterns, Edward Elgar, Cheltenham, 28-43

Audretsch, D.B. \& M.F. Feldman (1996), R\&D Spillovers and the Geography of Innovation and Production, American Economic Review 86, 630-640

Audretsch, D.B., M. Keilbach \& E. Lehmann (2006), Entrepreneurship and Economic Growth, Oxford University Press, New York, NY

Audretsch, D.B. \& A.R. Thurik (1999), Innovation, Industry Evolution and Employment, Cambridge University Press, Cambridge

Audretsch, D.B. \& A.R. Thurik (2001), What Is New about the New Economy: Sources of Growth in the Managed and Entrepreneurial Economies, Industrial and Corporate Change 10, 267-315

Baldwin, J.R. \& W. Gu (2011), Firm Dynamics and Productivity Growth: A Comparison of Retail Trade and Manufacturing Sectors, Industrial and Corporate Change 20, 367-395

Baptista, R. \& M.T. Preto (2011), New Firm Formation and Employment Growth: Regional and Business Dynamics, Small Business Economics 36, 419-442

Bettancourt, L., J. Lobo \& D. Strumsky (2007), Invention in the City: Increasing Returns to Patenting as a Scaling Function of Metropolitan Size, Research Policy 36, 107-120

Boschma, R. (2005), Proximity and Innovation: A Critical Assessment, Regional Studies 39, 61-74 
Brynjolfsson, E. \& L.M. Hitt (2000), Beyond Computation: Information Technology, Organizational Transformation and Business Performance, Journal of Economic Perspectives $14,23-48$

Bryson, J.R., D. Keeble \& P. Wood (1997), The Creation and Growth of Small Business Service Firms in Post-Industrial Britain, Small Business Economics 9, 345-360

Castells, M. (1996), The Rise of the Network Society, Blackwell, London

Chandler, A., P. Hagström \& Ö. Sölvell (1999) (Eds.), The Dynamic Firm: The Role of Technology, Strategy, Organization and Regions, Oxford University Press, Oxford

Coe, N., P. Dicken \& M. Hess (2008), Global Production Networks: Realising the Potential, Journal of Economic Geography 8, 271-295

Dejardin, M. (2011), Linking Net Entry to Regional Economic Growth, Small Business Economics 36, 443-460

Desrochers, P. (2001), Local Diversity, Human Creativity and Technological Innovation, Growth \& Change 32, 369-394

Doloreux, D. (2005), Regional Innovation Systems: Current Discourse and Unresolved Issues, Technology in Society 24, 243-263

Dreher, A., N. Gaston \& P. Martens (2008), Measuring Globalisation: Gauging its Consequences, Springer, Berlin

Dubina, I.G., E.G. Carayannis \& D.F.J. Campbell (2011), Creativity Economy and a Crisis of the Economy? Coevolution of Knowledge, Innovation, and Creativity, and of the Knowledge Economy and Knowledge Society, Journal of Knowledge Economy?, ?-?

Duranton, G. \& D. Puga (2001), Nursery Cities: Urban Diversity, Process Innovation, and the Life Cycle of Products, American Economic Review 91, 1454-1477

Duranton, G. \& D. Puga (2004), Micro-Foundations of Urban Agglomeration Economies, in Henderson, J.V. \& J.-F. Thisse (Eds.), Handbook of Regional and Urban Economics, Vol. 4, Cities and Geography, Elsevier, Amsterdam, 2063-2117

EIM (2009), Small Firms and Subcontracting, EIM/Panteia, Zoetermeer

Florida, R. (2002), The Rise of the Creative Class, Basic Books, New York, NY

Florida, R. (2009), Whose Your City?, Basic Books, New York, NY

Friedman, T.L. (2005), The World Is Flat: A Brief History of the Twenty-First Century, Farrar, Straus and Ciroux, New York, NY

Fujita, M. (2009), Dynamics of Innovation Fields with Endogenous Heterogeneity of People, in Karlsson, C., et al. (Eds.), New Direction in Regional Economic Development, Springer, Berlin, 59-78 
Glaeser, E.L. (2011), The Triumph of the City: Hoe Our Greatest Invention Makes us Richer, Smarter, Greener, Healthier and Happier, Penguin Books, New York, NY

Glaeser, E.L., et al. (1992), Growth of Cities, Journal of Political Economy 100, 1156-1152

Godoe, H. (2012), Innovation Theory, Aesthetics and Science of the Artificial after Herbert Simon, Journal of Knowledge Economy 3, 372-388

Hall, P. (1999), Cities in Civilization, Phoenix Books, London

Henderson, J., et al. (2002), Global Production Networks and Economic Development, Review of International Political Economy 9, 436-464

Iammarino, S. (2011), Regional Innovation and Diversity, in Cooke, P., et al. (Eds.), Handbook of Regional Innovation and Growth, Edward Elgar, Cheltenham, 143-154

Jacobs, J. (1969), The Economy of Cities, Random House, New York, NY

Karlsson, C. \& M. Andersson (2009), Entrepreneurship Policies: Principles, Problems and Oppurtunities, in Leitao, J. \& R. Baptista (Eds.), Public Policies for Fostering Entrepreneurship, Springer, Berlin, 111-131

Karlsson, C., B. Johansson \& R.R. Stough (2010), Introduction, in Karlsson, C., B. Johansson \& R.R. Stough (Eds.), Entrepreneurship and Regional Development. Local Processes and Global Patterns, Edward Elgar, Cheltenham, 1-27

Karlsson, C. \& R.G. Picard (2011) (Eds.), Media Clusters. Spatial Agglomeration and Content Capabilities, Edward Elgar, Cheltenham

Kenwood, A.G. \& A.L. Lougheed (1999), The Growth of the International Economy 18202000: An Introductory Text, Routledge, London

Kirchoff, B.A. (1994), Entrepreneurship and Dynamic Capitalism: The Economics of Business Formation and Growth, Praeger, Westport, CT

Klepper. S. (1992), Entry, Exit and Innovation over the Product Life Cycle, Paper Presented at the 1992 Conference of the International Joseph E. Schumpeter Society, Kyoto

Klepper, S. \& P. Thompson (2010), Disagreements and Intra-Industry Spin-Offs, International Journal of Industrial Organization 28, 526-538

Koellingar, P. \& A.R. Thurik (2012), Entrepreneurship and the Business Cycle, Review of Economics and Statistics 94, 1143-1156

Landry, C. (2008), The Creative City: A Toolkit for Innovators, $2^{\text {nd }}$ Ed., Earthscan, London

Lichtenhaler, U. \& E. Lichtenhaler (2009), A Capability-Based Framework for Open Innovation: Complementing Absorptive Capacity, Journal of Management Studies 46, 13151338 
Lucas, R.E. (1988), On the Mechanics of Economic Development, Journal of Monetary Economics 22, 3-42

Mankiew, G.N. \& P. Swagel (2006), The Politics and Economics of Offshore Outsouring, Journal of Monetary Economics 53, 1056-1086

McCann, P. (2007), Sketching Out a Model of Innovation, Face-to-Face Interaction and Economic Geography, Spatial Economic Analysis 2, 117-134

Montgomery, J. (2008), The New Wealth of Cities. City Dynamics and the Fifth Wave, Ashgate, Aldershot

Mowery, D.C. (2009), Plus ca Change: Industrial R\&D in the "third Industrial Revolution", Industrial and Corporate Change 18, 1-50

Neffke, F., M. Henning \& R. Boschma (2011), How Do Regions Diversify over Time? Industry Relatedness and the Development of New Growth Paths in Regions, Economic Geography 87, 237-265

Niebuhr, A. (2009), Migration and Innovation: Does Cultural Diversity Matter for Regional R\&D Activity? Papers in Regional Science 89, 563-585

Piore, M. \& C. Sabel (1984), The Second Industrial Divide, Basic Books, New York, NY

Porter, M.E. (1990), The Competitive Advantage of Nations, Macmillan, London

Puga, D. (2010), The Magnitude and Causes of Agglomeration Economies, Journal of Regional Science 50, 203-219

Rees, J. (1979), Technological Change and Regional Shifts in American Manufacturing, Professional Geographer 31, 45-54

Romer, P.M. (1990), Endogenous Technical Change Journal of Political Economy 98, S71S102

Sedgley, N. \& B. Elmslie (2011), Do We Still Need Cities? Evidence on Rates of Innovation From Count Data of Metropolitan Statistical Area Patents, American Journal of Economics and Sociology 70, 86-108

Shearmur, R. (2012), Are Cities the Front of Innovation? A Critical review of the Literature on Cities and Innovation, Cities 29, S9-S18

Storper, M. \& A. Venables (2004), Buzz: Face-to-Face Contact and the Urban Economy, Journal of Economic Geography 4, 351-370

Suarez-Villa, L. \& W. Walrod (1997), Operational Strategy, R\&D and Intra-Metropolitan Clustering in a Polycentric Structure. The Advanced Electronics Industry of the Los Angeles Basin, Urban Studies 34, 1343-1380 
Taylor, A.M. (2002), Globalization, Trade, and Development: Some Lessons from History, NBER Working Paper No. 9326

Thurow, L.C. (2002), Fortune Favours the Bold: What We Must Do to Build a New and Lasting Global Prosperity, The MIT Press, Cambridge, MA

Thurik. A.R., E. Stam \& D.B. Audretsch (2013), The Rise of the Entrepreneurial Economy and the Future of Dynamic Capitalism, Technovation 33, 302-310

Uhlaner, L. \& A.R. Thurik (2007), Postmaterialism Influencing Total Entrepreneurial Activity across Nations, Journal of Evolutionary Economics 17, 161-185

Vernon, R. (1966), International Investment and International Trade in the Product Cycle, Quarterly Journal of Economics 80, 190-207

Warda, P. (2013), Trends and Patterns in Offshoring in the European Automotive Industry, in Karlsson, C., B. Johansson \& R.R. Stough (Eds.), Entrepreneurial Knowledge, Technology and the Transformation of Regions, Routledge, London 118-143

Williamson, O.E. (1975), Markets and Hierarchies: Analysis and Antitrust Implications, The Free Press, New York, NY

Wolfe, D. (2009), $21^{\text {st }}$ Century Cities in Canada: The Geography of Innovation, Conference Board of Canada, Ottawa

Yeung, H. (2005), Rethinking Relational Economic Geography, Transactions of the Institute of British Geographers 30, 37-51 